\title{
KEBIJAKAN PENANGANAN MASALAH PERUBAHAN IKLIM DENGAN STRATEGI MITIGASI DAN ADAPTASI
}

\author{
Laili Rahmi* dan Relsas Yogica* \\ *) Mahasiswa Program Studi Pendidikan Biologi Program Pasca Sarjana (PPs) \\ Universitas Negeri Padang \\ mizz_lailye@yahoo.co.id
}

\begin{abstract}
ABSTRAK
Peningkatan suhu rata-rata permukaan bumi telah memicu terjadinya pemanasan global. Kondisi ini disebabkan oleh tingginya kadar emisi gas rumah kaca di atmosfir. Pemanasan global juga menyebabkan perubahan pola iklim. Dampak perubahan iklim mempengaruhi keadaan alam dan menyebabkan munculnya permasalahan pelik bagi kelangsungan hidup manusia, hewan maupun tumbuhan. Terdapat dua kerangka sebagai strategi utama dalam kebijakan penanganan masalah iklim ini, yaitu: mitigasi yang meliputi cara-cara untuk memperlambat emisi gas rumah kaca atau menahannya dengan upaya pengalihan penyerapan karbon dan adaptasi yang mencakup cara-cara menghadapi perubahan iklim dengan melakukan tindak penyesuaian yang tepat untuk mengurangi berbagai pengaruh negatif maupun pemanfaatan efek positif. Keberhasilkan upaya ini hanya akan dicapai jika setiap individu membangun kesadaran dan keikhlasan untuk melakukan perubahan demi mempertahankan keseimbangan iklim.
\end{abstract}

Kata kunci: Perubahan iklim, strategi mitigasi, strategi adaptasi

\section{PENDAHULUAN}

Dewasa ini, perubahan lingkungan dan perubahan iklim global semakin jelas dirasakan. Pola curah hujan cenderung berubah-ubah dan tak dapat diprediksi sehingga sewaktu-waktu dapat terjadi banjir di satu tempat namun kekeringan di tempat yang lain. Kondisi yang berlangsung sekarang ini jelas berbeda dengan kondisi beberapa tahun yang lalu. Konsep sebelumnya menerangkan bahwa Indonesia merupakan negara beriklim tropis yang mempunyai dua musim dalam satu tahun. Mulai dari awal tahun dalam kurun waktu 6 bulan ke depan, Indonesia akan mengalami musim kemarau dan 6 bulan selanjutnya akan mengalami musim penghujan. Siklus demikian telah mengalami perubahan seiring ketidakseimbangan lingkungan.

Perubahan iklim terkait dengan keadaan suhu lingkungan makro. Berbagai aktivitas manusia memicu emisi gas rumah kaca di atmosfer. Emisi gas ini selanjutnya berdampak pada kondisi klimaks terjadinya pemanasan global. Pemanasan global (global warming) tak terlepas pada kaitan dengan krisis iklim (climate crisis), dengan kata lain pemanasan global ini menyebabkan perubahan pola iklim.

Alam akan menunjukkan dampak oleh perubahan kondisi iklim yang tidak stabil. Hal ini selanjutnya menjadi permasalahan pelik bagi kelangsungan hidup manusia, hewan maupun tumbuhan. Keadaan akan menjadi klimaks bila tak adanya upaya kebijakan dalam penanganan.Oleh karena itu perlu perhatian banyak pihak untuk mengatasi permasalahan ini dalam tindakan yang dikenal dengan mitigation maupun upaya penyesuaian (adaptation).

\section{PEMBAHASAN}

\section{Global Warming oleh Greenhouse effect}

Pemanasan global secara konkrit diartikan sebagai peningkatan suhu rata-rata permukaan bumi. Hasil riset dalam publikasi ilmiah mengungkapkan bahwa peningkatan suhu lingkungan akibat adanya emisi gas rumah kaca (GRK) yang berasal dari aktivitas manusia. Gas ini pada dasarnya merupakan faktor pendukung kehidupan dibumi yang menyebabkan suhu bumi menjadi hangat. Namun sejak beberapa tahun belakangan ini, emisi gas rumah kaca terus mengalami peningkatan sehingga menyebabkan bumi diselimuti oleh gas tebal yang menghalangi pelepasan panas ke atmosfir. Peningkatan jumlah gas ini merupakan konsekuensi kegiatan yang tidak ramah lingkungan oleh manusia dalam pengelolaan lingkungan.

GRK adalah gas yang menyerap gelombang panas dari sinar matahari yang dipantulkan bumi. GRK yang penting ialah karbondioksida $\left(\mathrm{CO}_{2}\right)$, methane $\left(\mathrm{CH}_{4}\right)$, nitrous oxide $\left(\mathrm{N}_{2} \mathrm{O}\right)$, chloroflourocarbon (CFC) (yang dapat dibagi menjadi dua, yaitu: haloflourocarbon (HFC) dan perfluorocarbon $(\mathrm{PFC})$ ), selanjutnya sulfur hexafluoride $\left(\mathrm{SF}_{6}\right)$. Sumbangan terjadinya pemanasan 
global yang terbesar adalah $\mathrm{CO}_{2}$ sebesar $61 \%$, diikuti oleh $\mathrm{CH}_{4}$ sebesar $15 \%$, CFC sebesar $12 \%$, $\mathrm{N}_{2} \mathrm{O}$ sebesar $4 \%$ dan sumber lain sebesar $8 \%$ (Callan, 2000 dalam Sugiyono, tanpa tahun).

Framework Convention on Climate Change (UNFCCC) dalam Winarso (tanpa tahun) mengemukakan unsur-unsur yang termasuk dalam gas rumah kaca diantaranya $\mathrm{CO}_{2}, \mathrm{NO}_{2}, \mathrm{CH}_{4}, \mathrm{SF}_{6}$, PFCs, dan HFCs. $\mathrm{CO}_{2}, \mathrm{NO}_{2}$, dan $\mathrm{CH}_{4}$ sebagian besar dihasilkan dari pembakaran bahan bakar fosil baik dari sektor industri maupun dari transportasi. Sementara $\mathrm{SF}_{6}$, PFCs, dan HFCs sebagian besar merupakan hasil pemakaian aerosol.

Pemanasan global mengakibatkan lebih banyak air yang menguap keudara (yang akan memberikan umpan balik), yang tentunya akan mengakibatkan curah hujan meningkat (secara global $1 \%$ ). Seiring dengan peningkatan hujan dan kelembaban udara secara global, maka akan mempengaruhi kondisi iklim.

\section{Krisis Iklim (Climate Crisis)}

Badan Penerbangan dan Antariksa Amerika Serikat yang dikenal dengan NASA menyatakan bahwa pemanasan global berimbas semakin ekstrimnya perubahan cuaca dan iklim bumi. Pola curah hujan berubah-ubah tanpa dapat diprediksi sehingga menyebabkan banjir di satu tempat, tetapi kekeringan di tempat yang lain. Pemanasan global juga akan merubah selang waktu musim dimana musim hujan akan menjadi lebih lama dari pada musim kemarau atau sebaliknya, serta pergantian antara musim hujan dan musim kemarau ini dapat terjadi beberapa kali dalam setahun.

Dampak perubahan iklim bagi kondisi alam Indonesia, diantaranya: (1) suhu rata-rata tahunan menunjukkan peningkatan $0,3^{\circ} \mathrm{C}$ sejak tahun 1990, (2) musim hujan datang lebih lambat, lebih singkat, namun curah hujan lebih intensif sehingga meningkatkan risiko banjir, (3) variasi musiman dan cuaca ekstrim diduga meningkatkan risiko kebakaran hutan dan lahan, terutama di selatan Sumatera, Kalimantan, dan Sulawesi, (4) perubahan pada kadar penguapan air, dan kelembaban tanah akan berdampak pada sektor pertanian dan ketahanan pangan, (5) perubahan iklim akan menurunkan kesuburan tanah sekitar 2\% sampai dengan $8 \%$, (6) kenaikan permukaan air laut akan mengancam daerah dan masyarakat pesisir, (7) dampak terhadap potensi bencana yang dapat terjadi dalam jangka pendek maupun jangka panjang kehidupan.

Heru Santoso (2007) dalam Herawati (2007) pada lokakarya mengenai perubahan iklim, mengemukakan bahwa potensi jangka pendek dari perubahan iklim dapat memicu terjadinya katastropik dan pada jangka panjang menimbulkan perubahan ekosistem. Perubahan ini sebagaimana dikemukakan oleh Hairiah (2007) berkenaan dengan tingginya muka laut karena naiknya volume air yang mempengaruhi kehidupan di daerah pantai dan pemanasan global didaerah belahan Bumi Utara (Northern Hemisphere) yang mengakibatkan gunung-gunung es mencair dan daratan mengecil menyebabkan populasi flora dan fauna semakin terbatas.

Permasalahan yang terjadi dalam kehidupan manusia oleh perubahan iklim diantaranya: (1) transportasi dengan pelayaran kapal maupun penerbangan pesawat terkendala oleh cuaca yang buruk, (2) penanaman maupun pemanenan dalam sistem pertanian terganggu karena ketidakseimbangan iklim yang berlangsung, (3) bencana badai dan banjir mengancam keselamatan orang-orang yang berada di daerah tertentu, (4) peningkatan jumlah pengungsi suatu negara maupuan antar negara sehingga seseorang terpisah dengan akar sosial dan budaya mereka, (8) konflik horizontal yang memicu konflik politik karena peningkatan krisis pangan, air dan sumber daya.

Perubahan iklim juga berpengaruh bagi tumbuhan dan hewan diantaranya: (1) kekeringan yang menyebabkan tanaman menjadi layu, (2) ancaman kepunahan bagi beberapa spesies tumbuhan maupun hewan, (3) fragmentasi ekosistem seperti terumbu karang yang kehilangan warna karena paparan cahaya yang panas.

Irianto (2009) mengemukakan perubahan iklim dalam istilah anomali iklim terkait misalnya dengan ketersediaan air. Ketika terjadi anomali iklim, terutama yang menyebabkan kekeringan, maka tanaman pangan yang paling terpengaruh adalah yang membutuhkan banyak air seperti padi. Ketika musim tanam bergeser maju atau mundur dari yang dijadwalkan, tanaman akan mengalami kekeringan, sehingga produksi menurun. Selain menyebabkan penurunan produksi pertanian, kekeringan juga menyebabkan kebakaran hutan, seperti yang terjadi di Sumatera dan Kalimantan.

Pemanasan global akibat perubahan iklim pada wilayah tropis diperkirakan akan menurunkan produktivitas tanaman pangan apabila tidak dilakukan upaya antisipasi. Hal ini sesuai dengan yang 
diungkapkan oleh Tschirley (2007) dalam Irianto (2009), bahwa pemanasan global akan menurunkan produktivitas tanaman pangan secara signifikan, terutama di daerah tropis.

\section{MITIGASI DAN ADAPTASI PERUBAHAN IKLIM}

Pada awal tahun 1990 UNFCC sebagai institusi yang menangani masalah pemanasan global menetapkan konsep dalam kerangka dua strategi utama penanganan masalah iklim, yaitu: mitigasi dan adaptasi. Mitigasi meliputi pencarian cara-cara untuk memperlambat emisi gas rumah kaca atau menahannya, atau menyerapnya ke hutan atau 'penyerap' karbon lainnya. Sementara itu adaptasi, mencakup cara-cara menghadapi perubahan iklim dengan melakukan penyesuaian yang tepatbertindak untuk mengurangi berbagai pengaruh negatifnya, atau memanfaatkan efek-efek positifnya

Kondisi klimaks saat ini tidak berarti tak ada lagi upaya yang dapat dilakukan untuk mengurangi pemanasan global yang semakin meningkat. Ilmuan terkemuka NASA Dr. James Hansen menyatakan "Kita telah melampaui titik kritis, tetapi kita belum sampai pada titik tanpa harapan. Kita masih bisa berbalik, tetapi kita harus mengambil arah dengan cepat"(Hansen, 2008:19). Pada sebuah artikel Paris (AFP), Ketua Intergovernmental Panel on Climate Change (IPCC)- Rajendra Pachauri mengemukakan bahwa perubahan gaya hidup dapat mengerem perubahan iklim. Upaya ini merupakan unsur mitigasi.

Pemerintah sudah menyiapkan Rencana Aksi Nasional untuk Mitigasi dan Adaptasi Perubahan Iklim (RANMAPI). RANMAPI ini mengakui bahwa perubahan iklim merupakan ancaman serius terhadap pembangunan sosioekonomi dan lingkungan hidup Indonesia dan bahwa dampak perubahan iklim diperparah oleh pola-pola pembangunan yang tidak berkelanjutan

Keikhlasan dan kesadaran setiap individu untuk mengurangi semaksimal mungkin aktifitas yang memicu peningkatan emisi gas rumah kaca sangat berarti untuk mempertahankan keseimbangan iklim. Solusi yang dapat dilakukan diantarnya:

1. Mengurangi makan daging

Laporan PBB yang berjudul Livestock's Long Shadow: Enviromentallssues and Options (dirilis November2006) mencatat bahwa 18\%dari pemanasan global yang terjadi saat inidisumbangkan oleh industri peternakan. Penghitungan ini baru didasarkan pada emisi $\mathrm{CO}_{2}$, belum termasuk pencemaran pada tanah dan kandungan air bersih oleh limbah industri ini.

2. Penghematan energi bahan bakar fosil

Tindakan bijak dan efisien dalam penggunaan energi perlu dilakukan untuk mengurangi emisi gas rumah kaca. Beberapa diantaranya dengan mematikan peralatan listrik ketika tidak digunakan, menggunakan lampu hemat energi dan penggunaan alat transportasi alternatif. Terkait penggunaan transportasi alternatif ini Wakil presiden dari Uni Eropa Margot Wallstrom (2008:20) dalam Agus dan Rudi (2008) menyatakan "Saya berusaha untuk menggunakan sepeda untuk pergi ke tempat kerja sesering yang saya bisa untuk menghemat energi".

3. Melakukan penanaman pohon

Pohon berperan mengikat $\mathrm{CO}_{2}$ untuk mengurangi emisinya di lingkungan. Di samping itu berperan pula menjaga kesegaran udara sehingga mengurangi polusi.

4. Melakukan daur ulang (recycle)

Pendauran ulang perlu dilakukan untuk mengurangi emisi gas rumah kaca dan sebagai upaya menghasilkan energi alternatif bahan bakar. Sebagai contohnya dengan pembuatan biogas dari limbah yang selanjutnya dimanfaatkan sebagai bahan bakar ramah lingkungan.

Menanami kembali wilayah pesisir dengan hutan mangrove untuk meningkatkan penyerapan karbon juga termasuk tindakan mitigasi juga akan menguatkan adaptasi dengan memperkuat perlindungan terhadap badai dan erosi di wilayah pesisir.

Beradaptasi terhadap perubahan iklim merupakan prioritas mendesak bagi Indonesia. Seluruh kementerian dalam pemerintahan dan perencanaan nasional perlu mempertimbangkan perubahan iklim dalam program-program mereka berkenaan dengan beragam persoalan seperti pengentasan kemiskinan, pemberdayaan masyarakat, keamanan pangan, pengelolaan bencana, pengendalian penyakit, dan perencanaan tata kota. Namun ini bukan merupakan tugas pemerintah pusat belaka, 
tetapi harus menjadi upaya nasional yang melibatkan pemerintah daerah, masyarakat umum, dan semua organisasi non pemerintah, serta pihak swasta.

Berbagai persoalan besar seperti pengentasan kemiskinan, pemberdayaan masyarakat, perencanaan tata ruang, ketahanan pangan, pemeliharaan infrastruktur, pengendalian penyakit, perencanaan perkotaan, semuanya mesti ditinjau ulang dari perspektif perubahan iklim. Perbaikan pengawasan berbagaipenyakit, sistem peringatan dini dan respon terhadap bencana, perencanaan penanganan bencana, dan kesiapanuntuk menghadapi bencana kemarau panjang dan banjir.

Beberapa kebijaksanaantelah direalisasikan sebagai wujud adaptasi terhadap perubahan iklim. Perhatian terhadap orang-orang yang tinggal didaerah rawan banjir dengan memeriksakeamanan bangunan tanggul untuk penahan air.Di samping itu perlu penyuluhan bagi masyarakat untuk memahami tanda instruksi sebagai peringatan dini evakuasi sebelum banjir besar melanda. Terkait adaptasi terhadap kekeringan, parapetani diwilayah yang sering mengalami kemarau panjang sudah belajar untuk melakukan diversifikasi pada sumberpendapatan mereka, misalnya dengan menanam tanaman pangan yang lebih tahan kekeringan dan denganmengoptimalkan penggunaan air yang sulit didapat, atau bahkan berimigrasi sementara untuk mencari kerja di tempat lain.

Wujud adaptasi lainnya dapat dilakukan dengan menggunakan varietas yang lebih mampu bertahanterhadap kondisi yang ekstrem, kemarau panjang, genangan air, intrusi air laut, atau berbagai varietas padi yang lebih cepatusia panennya yang cocok untuk musim hujan yang lebih pendek. Para petani juga perlu mengupayakan cara-cara untukmeningkatkan kesuburan tanah dengan bahan-bahan organik bagi tanah supaya lebih mampu menahan air, yaitudengan menggunakan lebih banyak pupuk alamiah.

Penanaman kembali hutan atau pengalihan air antar waduk juga merupakan tindakan adaptasijangka panjang. Beberapa pilihan untuk menjamin pasokan air antara lain adalah dengan memperbaiki waduk,misalnya, menambal saluran, atau menampung air hujan. Pilihan lain adalah dengan mengurangi kebutuhan antara laindengan mengurangi kebocoran dari pipa-pipa atau melakukan lebih banyak upaya untuk memproses air limbahmenggunakan infrastruktur ramah lingkungan' seperti saringan pasir dan pengelolaan air limbah dengan tanaman rawa(wetlands).

Banyak tindakan adaptasi untuk kesehatan akan melibatkan penguatan sistem pelayanan dasar kesehatan danpengobatan yang sudah ada, misalnya dengan propaganda untuk meningkatkan kesadaran kesehatan kepada masyarakat agar lebih memperhatikankebersihan dan soal penyimpanan air

Perspektif terhadap mitigasi dan adaptasi dapat dipahami keterkaitannya, sebagai contoh: menanami kembali hutan-hutan kita, misalnya, bukan saja akanmeningkatkan penyerapan gas-gas rumah kaca, tetapi juga akan melindungi rakyat dari bencana langsung longsor.Menurunkan konsumsi bahan bakar di perkotaan tidak saja akan mengurangi emisi karbondioksida, tetapi juga akanmemperbaiki kesehatan penduduk kota dan meringankan beban rakyat, terutama yang masih anak-anak dan lansia dalambertahan pada kondisi cuaca yang ekstrem. Perubahan pelaksanaanpelaksanaan tersebut akan dapat dibenarkan dalamsituasi seperti apa pun, tetapi kebutuhan untuk beradaptasi terhadap perubahan iklim menjadikannya sebagai sesuatuyang lebih mendesak.

Akhirnya cara terbaik untuk beradaptasi terhadap perubahan iklim adalah beralih ke bentukbentuk pembangunan berkelanjutan, belajar untuk hidup dengan cara-cara yang menghargai dan serasi dengan alam. Perubahan iklimmerupakan ancaman yang serius yang menjadi suatu peringatan untuk menyadarkan kita. Namun, kita juga dapat menggunakankesempatan ini sebagai momentum baru bagi upaya-upaya perlindungan lingkungan hidup kita. Di Indonesia kitaberuntung memiliki sumber daya alam yang melimpah. Indonesia merupakan wilayah yang memilikikeanekargaman hayati yang paling kaya dan paling beragam di dunia. Semua itu sudah sepantasnya kita lestarikan sebagai warisan untuk generasi penerus. Namun, ada juga suatu kepentingan tersendiri yang kuat. Sejauh mana keharusan kitamenyelamatkan lingkungan, sedemikian pula kita bergantung pada lingkungan untuk menyelamatkan kita.

\section{KESIMPULAN}

Perubahan iklim sebagai dampak dari peningkatan suhu lingkungan oleh emisi gas rumah kaca yang pada kondisi klimaks mengakibatkan pemanasan global. Peran gas rumah kaca beralih dari faktor pendukung kehidupan di bumi menjadi ancaman seiring peningkatan emisinya di atmosfir. Pola iklim terus mengalami perubahan sebagai imbas dari pemanasan global yang semakin ekstrim. 
Dampak tidak hanya berkenanaan pada kondisi alam namun juga permasalah bagi manusia dan pengaruh bagi hewan dan tumbuhan. Perlu kebijakan dan perhatian untuk penanganan, berkenaan dengan ini UNFCC sebagai institusi yang menangani masalah pemanasan global menetapkan strategi penanganan masalah iklim, yaitu: mitigasi dan adaptasi. Mitigasi meliputi pencarian cara-cara untuk memperlambat emisi gas rumah kaca atau menahannya, atau menyerapnya ke hutan atau 'penyerap' karbon lainnya. Sementara itu adaptasi, mencakup cara-cara menghadapi perubahan iklim dengan melakukan penyesuaian yang tepat-bertindak untuk mengurangi berbagai pengaruh negatifnya, atau memanfaatkan efek-efek positifnya.

\section{DAFTAR PUSTAKA}

Agus R. dan Rudy S. 2008. Global Warming Mengancam Keselamatan Planet Bumi. Blog: hiduplebihmulia.wordpress.com, (Online), (http://afp.google.com/article/ALeqM5iIVBkZpOUA9Hz3Xc2u61mDlrwQ, diakses 15 Januari 2008)

Hairiah, K. 2007. "Perubahan Iklim Global: Dampak dan Bahayanya". Draft Modul 2. Malang: Universitas Brawijaya Fakultas Petanian Jurusan Tanah.

Herawati, H. 2007. "Laporan Diskusi Interaktif tentang Perubahan Iklim untuk Jurnalis" Makalah disajikan dalam Lokakarya Diskusi Interaktif tentang Perubahan Iklim untuk Jurnalis, Jakarta, 2 Mei.

Irianto, G. 2009. "Antisipasi Litbang Serealia dalam Menghadapi Dampak Pemanasan Global Guna Mendukung Kemandirian Pangan”. Makalah disajikan dalam Seminar Nasional Serealia.

Sugiyono, A. 2002. Penggunaan Energi dan Pemanasan Global: Prospek bagi Indonesia. Jurnal Ekonomi Lingkungan.

Winarso, P. A. Tanpa tahun. "Pemanasan Global dan Reduksi $\mathrm{CO}_{2}$ ". Makalah. Akademi Meteorologi dan Geofisika. 